\title{
Interview as a genre of new media communication: rhetorical relations and pragmatic effects
}

\author{
Inna V. Kovtunenko - Svetlana V. Bylkova - Viktoriya A. Borisenko - \\ Natalia A. Minakova - Varvara I. Rogacheva
}

DOI: 10.18355/XL.2018.11.02.08

\begin{abstract}
The article presents the results of the research of interview as a genre of new media. Special attention the article pays to rhetorical relations and pragmatic effects of the interview. On the level of new media, the genre of the interview realizes in a pragmatic aspect in two functions. These are messages and speech influence making. In private, the influence function is proved in a multidimensional way in the media discourse. Therefore, the addressee can believe in the speaker's correctness and accept his/her opinions in verbal expressions. We describe rhetorical relation schemes and models of the interview in new media, and its influence on the addressee in emotional and volitional ways. We can see the perlocutionary result of the interview in new media when the addressee creates meanings using communicative strategies in the mass media communication.
\end{abstract}

Key words: mass media, media discourse, new media, media genre, interview, rhetorical relations, pragmatic effects, influence, communicative strategies

\section{Introduction}

The interview as a specific genre of the journalistic activity reflects the overall pragmatic regularities of the dialogue organization: the interlocutors do not only exchange alternately with the communicative positions of the speaker and the recipient, but also the spontaneous processes of intention expressing and perceiving messages are associated with the specificity of the addresser and the addressee's language consciousness. Initiating dialogic moves, the interviewer and the respondent attempt to capture the actual speech content, endowed with the personal meanings. Creating the personal meaning, i.e. a projection of one's own methods of influence on individuals in the various local situations necessarily presupposes the formation of the speaker and the addressee's images in the interlocutors' consciousness (Galushkin, $2017 \mathrm{a}, \mathrm{b})$. In this aspect, the processes of speaking and listening appear to be active, communicative settings, which are the consequences of the participants' communicative competences.

Under the impact of drastic shifts and transformations in mass media reporting (Thompson, 1995; Jamieson, Campbell, 1997; Zheltukhina, 2003; Pavlic, 2009; Zheltukhina et al., 2017b, Zheltukhina et al., 2017a) the styles of mass media as a discursive sphere of the literary and figurative language is undergoing decisive changes, requiring deep and comprehensive linguistic understanding (Minakova, 2011). The dominance of oral and electronic media marks the transition from the purely journalistic grounds of the functioning of this style of information and journalistic discourse. Consequently, the nomination of the style itself has changed: instead of the concept of "journalistic style", the contemporary linguistic science updates the term "the style of mass media communications".

The linguistic research of the genre differentiation of mass media style and the analysis of interview genre allow making the conclusion that the traditional division of genres on the level of subjective and substantive perspectives (the speaker's modality manifestation in the text) is not consistent with the linguistic and stylistic directions of the genre differentiation. The genres of mass media communication

XLinguae, Volume 11, Issue 2, April 2018, ISSN 1337-8384, eISSN 2453-711X 
could be analyzed logically as informative and publicist varieties, whereas in journalistic categorizations diverse analytical genres are also steadily identified.

\subsection{Theoretical research base: the condition of problem's study}

In the current linguistic and journalistic researches, the interview is characterized clearly with the phenomena that this kind of genre (Rubinstein, 2000; Ilchenko, 2002; Coats, 2004; Witosh, 2005; Borisenko, 2016) reveals systemically informative and publicist genre varieties; thematic/rhematic modeling; author's and addressee's speech relationship peculiarities; specific linguistic and pragmatic features of mass media communication; diversified discourse influence ways in new kind of mass media.

Linguistic and pragmatic investigating of the discursive and communicative models concerning the speech act theory is directed at revealing the extra-linguistic basis of selecting the means of impact on the respondent allowing the sender to accomplish the perlocutionary aims of his/her dialogic actions (Tarde, 1969; Jacobson, 2000; Olyanich, 2007; Issers, 2008; Bylkova, 2014; Borisenko, 2016; Kovtunenko, Postevaya, 2017, Zhetukhina et al., 2017a). In the linguopragmatic aspect, it seems probable to differentiate systemically the semantic levels, which are actualized in various genres of discursive activity as the sequence of choosing the semantic and pragmatic means of impact. In the linguistic pragmatic dimension, the interview speech genre realizes such principles as discursive validity and intentionality. The pragmatic features of the contemporary interview are based upon the generic dialogic modeling of human communication in the frameworks of new mass media. «The nearest social situation and the broader social environment entirely determine ... the statement structure» (Bakhtin, 1993). We understand «the speech genre» according to K.F. Sedov (1999): «not taking into account social facts, events, circumstances, verbal and non-verbal manifestations and embodiments would mean necessarily to oversimplify compound social and communicative exchanges». Therefore, the speech genre analysis focuses on the dialogical communication, social, spiritual and cultural aspects. The interview is basically characterized by implicit spontaneous expression of the participants' dialogic intentions, while under the "implicit expression" we comprehend the contextual use of language means, as the context is considered as an integral component of the ongoing senses. Any language functioning is determined by context. In the interview, for example, the total context in which the dialogic exchanges take place, is not strictly fixed, the interviewer and the respondent, relying on particular linguistic means, their functional and pragmatic features, mutually design and reproduce it.

The rhetorical structure theory explores the specificity of text functioning in the real communication context (Mann, Matthiessen, Thompson, 1992), is considered the descriptive linguistic approach to a wide range of phenomena that are associated with text organization in the aspect of the semantic relations established between the text segments. This theory explains the pragmatic nature of speech work integrity based on the hierarchical relations between the text segments. It is postulated that each segment performs the specific semantic function, connecting with the subsequent segment. The text coherence («discursive relationship») is determined by the relationship within the speech work, involves the identification of the intentional use of individual text segment. The hierarchy of these segments, in turn, suggests their correlation based on such concepts as «nuclear», and «the semantic relation type». The theory offers the principle of compositionality: the two text segments are connected with the rhetorical relations that occur between the two essential components, that is the nucleus and its subsidiary relationships. As a constructive, the opposite pattern is also interpreted: in the process of building a scheme of the rhetorical text structure, the discourse relations between two of its important segments occur when these relationships are traced within these two segments (Marcu, 1996).

The analyzed theory also traces what underpins the text hierarchical structure 
organization in the process of creating its coherence, whether the connected text segments manifest the integral propositional content. The source of the text coherence, its integral unfolding is the speaker's intention to influence the recipient. The semantic relations and hierarchy of these relations between the segments form the text rhetorical structure, model its coherent nature.

\section{Methodological Bases and Research Methods}

According to the purpose and problems of the research, we have defined the following methods of our analysis: hypothetical-deductive method, inductive method, descriptive and comparative methods, linguistic and pragmatic analysis, elements of cognitive interpretation. The pragmatic validity of the interview text is the main approach in our research. This theoretical approach is based on the analyticity and publicity in journalism, linguopragmatics, linguostylistics. The interview as an interspecific genre in new mass media makes an autonomous communicative group. The linguopragmatic analysis of the essence of the dialogism suggests that the interview genre, due to the system of the interlocutors' linguistic relationships, in the contemporary global communication displays the language practices of impact on the single information space modeling, the process of dialogization of the space.

\section{Results and Discussion}

\subsection{Interview and Casual Conversation: Common and Different Features}

If we take into account the fact that individual communicative competence in particular social and cultural framework allows adopting the speech behavior in accordance with the communicative context, we admit that such contexts are modeled by specific rules and norms of the language use (Borisenko, 2016; Kovtunenko, Postevaya, 2017). In the interview text, the researcher reveals the joint participation of interlocutors in reproducing the meaning, which is relevant to the readership. The basic form of this process is the image generation. The interviewee supplements the previously indicated situation; the readers create their own image based on the image offered. The strength of the image, transmitting the meaning and emotions, is its ability to detail the actual situation in the context of the speech event. The images as well as the dialogue, design the speech event.

At the level of the interview text, the linguistic analogy contributes to the generation of joint images through which the communication between the interviewee and the reader turns out to be possible. The spontaneous dialogue creates a unique semantic space, which makes it possible to involve the reader into the interviewee's personal space and the "invasion" of the interviewer into the readers' personal space. The speech event context determines the fact whether it is possible to label this spontaneous dialogic communication as an interview. Naturally, the successful cooperation will be structured around the factors such as the participants' discursive roles, appropriate use of the language and speech means, the communication style. The readers extract the understanding from the detailing because it reflects the information personally meaningful to the interviewee (Bylkova, 2014). Through the images partially generated by the detailing, the reader constructs his or her own cognitive image of the situation. The thorough nature of detailing allows both the interviewee and the reader to actualize the individual presuppositions, construct an individual image of the situation: the relationship of creative personalities in the recognizable activities. At the text level of the conversation, the simultaneous construction of the situation in the cognitive consciousness of the interviewee and the reader gives rise to the process of their joint participation in meaning production. The situation of communication in a casual conversation between two acquaintances is consistent with a set of rules of the dialogic exchange, the participants' interaction control on this exchange, which is based on special sensitivity to the recipient's needs.

XLinguae, Volume 11, Issue 2, April 2018, ISSN 1337-8384, eISSN 2453-711X 
The interview situation pursues a different set of norms of interaction and interpretation that are modeled in the question-answer dynamics of communication. In the latter case, the interview participant is responsible for the dialogic replica content, the choice of the subject under discussion and in terms of the interviewee for the relevant answers, predetermined results of the speech event. Failure to comply with any of the norms may cause "slip" in the speech event. However, the communication will be regarded as an interview. If the deviation from the norm affects the results of the speech events, it will inevitably "collapse" the dialogic communication as the form of the interview. For example, if one participant begins to dominate, the interview transforms into a casual conversation, "monologue to the listener".

The informal communication as a structural component of the social communication, has the following dissimilarities from official media communication: the specificity of the subject and the object structure; the conditions of formation (weak influence of formal social structures, informal nature of the situation, strong interpersonal interaction, confidence, importance of judgments about the information); the importance of an intermediary addressee, that is the readers' audience for which the information is presented in the relevant to the audience context. The informal interview genre is the realization of two functions: messaging and influencing. The previous function is the most evident in the journalistic style, where the main objective is to convince the addressee of the correctness and the adoption of the perspective of the text sender. This purpose is achieved in journalism through logical reasoning and emotional influence. Both effects are used in the informal interview genre in new media communication.

The informal interview genre, in other words, reflects a general dialogue pattern: the partakers don't only exchange with the communicative roles of the addresser and the recipient of the message, but the processes of speaking and listening involve the preservation in the simulated speech situation the features of the linguistic consciousness of the dialogue participants. In the process of generating the statements and judgments, the interviewer and the interviewee attempt to capture the relevant, pragmatic sense, personal in its pragmatic and cognitive nature.

\subsection{The interviewer, the respondent, and the reader}

The interviewee's narrating on his/her personal experience for the reader's audience predetermines the speech events that go beyond the common dialogical move exchange. As J. Coates notes, the interviewer is considered a passive partaker in the spontaneous dialogue, raising the questions on behalf of the readers' audience (Coats, 2004). The interviewee shows the competence in defining what dialogic points could be characterized with particular sensitivity to the reading audience's interests and constructs the conceptual content of his/her moves accordingly often creating even the fictional images.

The spontaneous dialogic communication between the interview partners is not only about the information exchange but represents a convergence of their ideas about themselves and the objective world in order to attract and gain the readers' interest (Ilchenko, 2002; Makarova, 2003). The more similar the interlocutors' pictures and models of the world, the faster and easier the interlocutors achieve the coherence of their points of view. The interviewer seeks to reconstruct the interviewee's inner world in order to provide the reader with his/her feelings, motives, verbal / non-verbal behavior, attitudes to the important objects. A constructive role in this process is played by language stereotypes that govern the process of spontaneous communication: similar ideas about the phenomena find themselves the subject of discussion, promote mutual understanding between the dialogue participants. The interviewee while implementing his/her response is hampered by socio-cultural conventions, the interviewer's linguistic personality peculiarities, the recognition of which not only extends the interviewee's speech abilities but also simulates his/her 
communicative behavior. As soon as the interviewer starts talking about his interlocutor and represent him/her in his speech, the interviewee is enslaved by the language system, inscribed in the categorical grid of the interviewer and his experience of the existential existence, thus he/she loses his/her self and becomes a part of the interviewer's discourse.

\subsection{The interview as a productive speech genre of new media}

The respondent's narrative should satisfy certain criteria in order to fulfill its social functions. The main criteria are objectivity, credibility, responsibility, simultaneous updating of praise and blame. These criteria help a competent narrative addressant to take account of knowledge about his/her interlocutor's interests, needs, and current emotional state. Therefore, the interviewee is to manifest himself/herself in the media conversation as the experienced communicator predetermining the positive reaction of the addressee. Specifically, the interviewee models the narrative images that use fragments of the private life.

One of the features of the quality postulate in the interview genre is that the interviewee may break it invisible to the interviewer. However, this is only possible if the interviewer is familiar enough with the situation and not aware of the possibility of deception. It should be noted that the three postulates of the cooperation principle in the interview genre much easier to control based on the specific dialogic situation without any additional factual information. The interviewer must rely on the interviewee's sincerity. Adherence to the quality postulate, unlike other rules of cooperation, is difficult to control based on the momentary interview situation, as this in most cases, it is necessary to know in advance the true state of things. That is why the interviewee takes the control over observance of the quality postulate. The readers' interests require this. The interviewee takes over the control over the observance of the three remaining postulates, as it is easier to assess what information and in what quantities the interviewer and audience need. The language, therefore, is designed so that it allows the interview participants to usurp the language as a whole. The language provides kind of "empty" forms, which each speaker appropriates and applies to his/her own "face", at the same time defining himself/herself as "I", and partner as "you". The assignment process is performed in an individual act of utterance. As the subject, equal to the speaking personality, the interlocutor acts as a stranger, an outsider - someone, alienating the world and the speaker's opportunities: I catch the gaze of the other inside one's own actions as the solidification and alienation of my own possibilities. The interviewer perceives not only the interviewee but turns him/her into an object of consideration. In this regard, the interviewer takes care of his/her dialogic move pragmatic organization, correcting his/her statement in accordance with the external manifestation of the interviewee's response.

The interviewee's presence in the spontaneous conversation predefines the following language features of the interview genre:

- the interviewee is present in the interviewer's retold speech: using his/her own words, the interviewer refers to other as a source of "meaning" of the transmitted text. In the direct speech, the words themselves take time (or space), clearly identified in the proposal as a quote, while the interviewer acts as a simple "horn". In these two different ways, the interviewer explicitly refers in his/her speech the place of interviewee's speech;

- to the interviewees point out the references to other, already existing discourse. This is a large area of embedded quotations, allusions, stereotypes, allusions when these fragments are designated as "taken from another source";

- in the case of indirect speech, irony, antipathy, imitations, allusions, reminiscences, stereotype the availability of interviewees is not clearly marked. This kind of "games with others" in the discourse is observed in the space of inexplicit

XLinguae, Volume 11, Issue 2, April 2018, ISSN 1337-8384, eISSN 2453-711X 
ideas, but not explicit and expressed ones.

Interpersonal interaction practices actualize the relationships between informative spheres and interlocutors' systems of conceptual representations; form the paradigm of linguistic and stylistic specifics of the interaction. For dual addressing in the interview genre, the respondent has speech impacts on both the interviewer and the readership. The structured verbal interaction between the interlocutors in the spontaneous conversation is determined by such interviewee's communicative strategies as personal sense actualization, the reflection of interpersonal relations with the interviewer, optimization of the spontaneous communication. The relevance of the interview for the written discourse predetermines the interviewee's communicative strategy actively involving the reader in the dialogue, which is implemented in the form of such tactics as the construction of verbal images and descriptive realization of illocutionary forces of the replica-reactions, a denial of the facts, actualized in the interviewer's dialogical replicas.

\subsection{Rhetorical relations in the interview text}

The interview text is a rhetorical tool of communication, a tool whereby the interaction between the interlocutors (speaker and hearer, author and reader), the pragmatic nature of which is reflected in the communicative purpose of the text.

The interview itself is determined by the goals of the interlocutors and is therefore rhetorical in nature: the purposes of the communicative events form the contexts of communication, which contribute to the formation of the text samples relevant to the definite discourse communities. The rhetoric nature of the interview text in the framework of our research has two important research implications: (1) language is used as an effective tool of the communicative text purpose realization; (2) the interview genre provides a sample of the text organization, appropriate language use, the prevalence of the definite text characteristics and structures. In this regard, the interview text microstructure should "be interpreted as a rhetorical structure, which is motivated by the global function of the text" (Levinson, 1983; Heuboeck, 2009). The rhetorical function of the interview text contributes to the modeling of the building blocks to ensure the global coherence of the text. The rhetorical structure can, therefore, be represented as predefined in terms of the syntagmatic relations, which provide the global text coherence.

In this article, we analyze concessive rhetorical relations in the informal interview text. In the informal interview text, the concessive rhetorical relations appear to be the pragmatic indicator of the communicative interaction models. Making concession in favor of the interlocutor's semantic position the speaker introduces the alternative point of view on the problem under discussion. In this regard, in the interview text, the concession appears as a form of contrast expression: contrast is "eclipsed" by the concession, and so the interaction becomes non-confrontational in nature.

In the interlocutors' speech, the rhetorical concessive potential is manifested in the base model consisting of three sequentially implemented components of its structure:

(X) the expression on the interviewer's standpoint through narrative or interrogative dialogical replicas;

(X') the partial agreement with this point of view on the respondent's part, which manifests an assignment in favor of the interviewer's semantic position;

(Y) the potentially contrasting dialogical step, which manifests the alternative opinion on the situation under discussion.

The structural marking of concessive rhetorical relations in the interlocutors' speech steps suggests the preferential use of conjunctions but (dominant) and although (less frequent) that limit the validity of the previously expressed proposition and introduce the additional relevant information. The conjunction but also provides the space for communicative maneuver in case of the divergence between the interlocutors' semantic positions, maintains the informal interaction partners' "social face". The 
conjunction although introduces a proposition that summarizes the information actualized in the preceding dialogical interaction.

The concept of concessive rhetorical relations acquires research importance primarily in the following aspects, and that as a type of cohesion between:

- the main and the subordinate parts in the complex sentence;

- the segments in the whole informal interview text.

- In the informal interview the reacting partner, as a rule, does not refute the arguments previously put forward by the speaker, resorts to the grammatical sustainable models by which - not always relying on the formal indicators - he/she expresses the acknowledgment that the situation / the fact / the phenomenon that was previously covered the speaker is true / effective / effective.

The concessive relationship between the dialogic text components is dyadic in its fundamental nature, as it involves the participation of both parties: the interviewee interlocutor implements the concession, the interviewer, whose preliminary replica appears to be the basis for the initiation of the concession. The model of the rhetorical relation realization involves the interlocutors' equal participation. One of the interlocutors concedes to the other interlocutor in the aspect of the situation under discussion. The interaction partner, who makes the concession, implements the potentially contrasting conclusion. The potential contrast cognitive nature is based on the interlocutors' ability to make the deductive knowledge from the speaker's dialogic replica. In other words, the elements of the situation under discussion $(\mathrm{X})$ and $(\mathrm{Y})$ are taken by the informal interview participants as a contrast, not a priori but are interpreted as such in the dialogic situational context.

The examples collected in our corpus, provide an opportunity to identify the length of dialogical steps, forming the basic model of concessive rhetorical relations in the informal interview text. These dialogic steps include, as a rule, the complex sentences. We give below one of the most typical examples (the participants of the informal conversation discuss the problem of the penal system, in which the individuals who have committed serious offences do not go to jail, but wear the wrist bracelet with an electronic sensor):

"(X) - Everybody knows whoever you see they know you've done something, where as you know, once you're going all away, a lot of people could just think you've gone on a holiday or something like that.

(X') - I suppose they could. Yes, I suppose it would mean that you'd have to spend quite a lot of time indoors, or else you'd have to wear a large muffler all the time, or pretend you had a stiff neck, and wear one of those big pink things they give you. - Yes.

(X') - ... or something like that...

(Y) But I must say I think it's the one sort of opinion I have on the matter. I think I would rather that than go to prison, because prison must be very soul destroying, don't you think?" (London Paper, 2014, № 21, p. 13).

In the dialogical step $(\mathrm{X})$, which is a complex sentence, the interviewer speaks in favor of the offender in prison. The respondent implements the concession to the interviewer's opinion. The dialogic step (X') is a combination of simple and complex sentences. Further, the interviewer acknowledges the respondent's concession. At this point, the respondent again confirms the concession to the interviewer's opinion (... or something like that...) and implements an alternative view (Y) (But I must say...), which is also issued by means of the complex sentence. Thus, the dialogic steps (X), $\left(\mathrm{X}^{\prime}\right)$ and $(\mathrm{Y})$ forming the rhetorical concessive relation basic model include complex sentences or combinations of simple and compound sentences. Components (X') and (Y) form the respondent's dialogical steps, i.e. describe the same participant in the informal interview. These dialogical steps are combined into one coherent sequence. The respondent, reacting to the interviewer's replica (X), connects the dialogic steps

XLinguae, Volume 11, Issue 2, April 2018, ISSN 1337-8384, eISSN 2453-711X 
(X) and (Y) by the adversative conjunction but.

The following example shows that the dialogic steps can also be connected with other subordinating conjunctions (the informal conversation is focused on the fact that the low-quality meat should not be used in canned food for dogs). Cf.:

"- I just wonder why we should worry too much about what we put in their food as soon as you let them off the lead, or as soon as we see people let them off a lead, they immediately go sniffing round picking up all and sundry from the ground,

(X) and I just wonder what's the point in worrying about what goes in the tin.

(X') - Well, yes,

(Y) except that I mean you have to recognize as Mrs. Sack said that there are a great many people whose lives are built round to some extent their pets..." (Country Weekly, 2014).

The interviewer's illocutionary intention is to express a judgment (in the form of the hidden rhetorical question) that there is no need to worry about the contents of the cans. The respondent initially agrees with the interviewer (well, yes). However, he immediately formulates the point of view, according to which he does not actually agree with the initial position, pointing to the need to recognize the fact that too many people focus on pets (...you have to recognize... that there are a great many people... whose lives are built round their pets). From the views expressed it follows that dog owners do the right thing, being concerned about the health of their Pets. In the respondent's dialogic move $(\mathrm{Y})$ is connected with the previous step (X') with the subordinate conjunction except that.

The rhetorical concessive relation basic model in the informal interview text is characterized by such parameters as:

- the explicit expression of the interviewer's step (X) and the respondent's steps (X') and $(\mathrm{Y})$;

- the order of the dialogue steps between the interviewer and the respondent, namely $(\mathrm{X}),\left(\mathrm{X}^{\prime}\right)$ and $(\mathrm{Y})$.

The respondent's replica expresses the adversative non-conflict compromise that is based on the idea of the partial inconsistency of the interlocutors' semantic positions. Explicating this principle, the respondent focuses the readers' attention to a particular fact or event from his/her private life or professional activities, which deny the absolute truthfulness of the information provided by the interviewer in the initial replica. In this case, the principle of the compromise is frequently expressed with the adversative conjunction but.

\section{Conclusion}

In the interview in new media communication, the concessive rhetorical relations can be viewed as a tool that converges the speech genres of the informal interviews and the everyday conversation. In both speech genres, the actualization of the important information by way of concession is associated with the fact that the speaker has the specific interpretation of his/her utterance and expects that the addressee can interpret this statement in the same way. The concession appears to be a predictor of the relevant dialogical interpretation of the replicas. The pragmatic function of the concession is to stimulate the process of dialogic step relevant interpretation by specifying the context of its use and the specifics of the speech event, modeled according to the context.

As shown by our finding, on the level of the informal interview text the concessive rhetorical relations represent a three-part sequence of the interlocutors' dialogic steps, within the framework of the unfolding of which the speaker is the subject pushes a value judgment $(\mathrm{X})$, and the addressee agrees with this judgment or makes a concession in favor of its efficacy (X'), but also potentially puts forward a contrasting argument $(\mathrm{Y})$. This sequence of interlocutors' verbal steps, in turn, creates the rhetorical concessive relation basic model in the informal interview text. The contrast 
between the interviewer and the respondent's positions emerging in the informal conversation is "eclipsed" by the concessive rhetorical relations, and therefore in the spontaneous interaction, the conditions are created for the non-conflict achievement of the consensus. The basic rhetorical concessive relation model assumes the equal weight of the two potentially incompatible perspectives in terms of the events, phenomena, facts under discussion, as well as the objects discovered in these events, phenomena, and facts. In particular, limiting the validity of the preceding proposition at the level of individual speech turn is considered as the strategy aimed at preventing the unwanted comment from the interviewer. The function of concessive relations is also actualized for obtaining the interviewer's consent with the view presented by the respondent. The dissimilar interlocutors' positions are manifested by such model components as $(\mathrm{X})$ and $(\mathrm{Y})$, the dialogic step (X') expresses the reacting interlocutor's consent with the pre-initiated point-of-view (X) which belongs to other interlocutor, the concession in favor of his/her position. The concession, in turn, becomes the basis for presenting the alternative views $(\mathrm{Y})$ reflecting a different view on the problem under discussion. The components (X) and (Y) are implemented mainly at the level of the dialogic moves taken by the same interview participant. The contextual meaning of the concessive rhetorical relations reveals the semantic content about the respondent's "Ego" in connection with the emotional experience once gained life experience, shifts the focus of attention in the spontaneous interaction into the dimension of the message context about this experience. Concession expressed by the respondent in favor of the interviewer's opinion gives him/her the opportunity to report what he/she remembers in terms of the event or fact under discussion. The pragmatic function of the concessive rhetorical relations in such dialogical context is to provide the detailed representation of the events under discussion from the point of view of the subjective perspective different from that of the interviewer.

\section{Bibliographic references}

BAKHTIN, M.M. 1993. Marksizm I filosofiya yazyka. Moscow: Labyrinth. ISBN 587604-016-9.

BORISENKO, V.A. 2016. Politicheskoye intervju: pravila I normy vedeniya kriticheskoy diskussii. In: Gumanitarnyje I sotsial'nyje nauki, n. 6, pp. 49-56. ISBN 2070-1403.

BYLKOVA, S.V. 2014. Funkcionirovanie pobuditel'nych predlozhenij v faticheskom obshenii. In: Vestnik Irkutskogo gosudarstvennogo tehnicheskogo universiteta, vol. 10, n. 93, pp. 288-293. ISBN 1814-3520.

COATS, J. 2004. Succeeding at Interviews. Oxford: HowtoBooks. ISBN 978-184803-255-2.

GALUSHKIN, A.A. 2017a. Operational management of enterprise structures in the sphere of education and science: Problems and methods for their solution. In: European Research Studies Journal, vol. 20, n. 4, pp. 412-420. ISSN: 11082976.

GALUSHKIN, A.A. 2017b. Organizations of the sphere of education and science methods of competitiveness improvement. In: European Research Studies Journal, vol. 20, n. 4B, pp. 421-431. ISSN: 11082976.

HEUBOECK, A. 2009. Some Aspects of Coherence, Genre and Rhetorical Structure - and Their Integration in a Generic Model of Text. In: Language Studies Working, n.

1, pp. 35-45. ISSN 2040-3461

LONDON PAPER. 2014. How to deal with offenders? Interview with Amanda

Menson. In: London paper, n. 21, pp. 13-14.

ILCHENKO, S.N. 2002. Intervju v zhurnalistskom tvorchestve. Saint-Petersburg:

Saint-Petersburg University. Available online: URL:

http://jf.spbu.ru/upload/files/file_14666740-39_3087.pdf

ISSERS, O.S. 2008. Kommunikativnyje strategii I taktiki russkoj rechi. Moscow:

XLinguae, Volume 11, Issue 2, April 2018, ISSN 1337-8384, eISSN 2453-711X 
Editorial URSS. ISBN 978-5-382-00698-7.

JACOBSON, R. 2000. Linguistics and Poetics. New York: Routlenge, 334-340. ISBN 0-415-18681-1

JAMIESON, K.H. - CAMPBELL, K.K. 1997. The Interplay of Influence: News, Advertising, Politics and Mass Media. Belmont: Wadsworth Publishing Company. ISBN 9780534533649.

KOVTUNENKO, I.V. - POSTEVAYA, E.V. 2017. Pragmaticheskiye aspekty issledovaniya nevezhlivogo I jumoristicheskogo dialogicheskogo teksta. Rostov-onDon: AkademLit. ISBN 978-8-904067-17-5.

LEVINSON, S.C. 1983. Pragmatics. Cambridge: Cambridge University Press. ISBN 978-0521294140

MAKAROVA, I.V. 2003. Neformalnaya kommunikatsiya: Abstract of PhD. Rostovon-Don.

MANN, W. C. - MATTHIESSEN, I. M. - THOMPSON, S. A. 1992. Rhetorical Structure Theory and Text Analysis. Amsterdam: John Benjamins. ISBN 213 8221511.

MARCU, D. 1996. Building up Rhetorical Structure Trees. In: Proceedings of AAAI, n. 96, pp. 1069-1074, Portland OR. ISBN 978-0-262-51091-2.

MINAKOVA, N.A. 2011. O yazyke i stile nauchno-populyarnogo mediateksta. In: Vestnik RUDN. Seriya «Russkij i inostrannyj yazyki i metodika ikh prepodavaniya», vol. 4, pp. 27-34. ISSN 2313-2264.

OLYANICH, A.V. 2007. Prezentatsionnaya teoriya diskursa. Moscow: Gnosis. ISBN 5-7333-0184-8.

PAVLIC, J.V. 2009. New Media Journalism. In: 21st Century Communication, vol. 1, n. 2, pp. 643-651. ISBN 1412950309.

COUNTRY WEEKLY. 2014. Pet saved me with HeimLick. Interview with Tone Bassett, pp. 43-44.

RUBINSTEIN, S.L. 2000. Osnovy obshej psichologii. St.Petersburg: Piter. ISBN 5-31400016-4.

SEDOV, K.F. 1999. Stanovlenije discursivnogo myshleniya yazykovoj lichnosti: Psicho- I sotsiolingvisticheskije aspekty. Saratov: Saratov University. ISBN 5-2920233-7.

TARDE, G. 1969. On Communication and Social Influence. Chicago: University of Chicago Press. ISBN 0226789713.

THOMPSON, J. 1995. The Media and Modernity: A Social Theory of the Media. Cambridge: Polity Press. ISBN: 9780804726795.

WITOSH, B. 2005. Linguistic Study of Genres. Problematic Aspects. Katowice: Publisher University of Silesia. ISBN 83-226-1495-0

ZHELTUKHINA, M.R. - BIRYUKOVA, E.V. - GERASIMOVA, S.A. - REPINA, E.A. - KLYOSTER, A.M. - KOMLEVA, L.A. 2017a. Modern Media Advertising: Effective Directions of Influence in Business and Political Communication. In: Man in India, vol. 97, n. 14, pp. 207-215. ISSN: 0025-1569.

ZHELTUKHINA, M.R. - MOUZYKANT, V.L. - BARABASH, V.V. PONOMARENKO, E.B. - MOROZOVA, E.V. - MORI, S. 2017b. Russian and Japanese Younger Generations in Search for a New Media Product. In: Man In India, vol. 97, n. 3, pp. 223-236. ISSN: 0025-1569.

ZHELTUKHINA, M.R. 2003. Tropologicheskaya suggestivnost' massmedial'nogo diskursa. Volgograd: IYA RAN, VF MUPK. ISBN 5-88234-568-5.

Words: 5770

Characters: 39761 (20,09 standard pages)

Associate Prof. Inna V. Kovtunenko, PhD.

Institute of Philology, Journalism and Intercultural Communications 
Southern Federal University

33 Bolshaya Sadovaya Str.

344006 Rostov-on-Don

Russia

iv.kovtunenko@yandex.ru

Associate Prof. Svetlana V. Bylkova, PhD.

Faculty of Social and Human Sciences

Don State Technical University

1 Gagarin Sq.

344000 Rostov-on-Don

Russia

svetby17592@rambler.ru

Associate Prof. Viktoriya A. Borisenko, PhD.

Institute of Philology, Journalism and Intercultural Communications

Southern Federal University

33 Bolshaya Sadovaya Str.

344006 Rostov-on-Don

Russia

v-bor@yandex.ru

Associate Prof. Natalia A. Minakova, PhD.

Faculty of Philology

Peoples' Friendship University of Russia

10/2 Mikluho-Maclay Str.

117198 Moscow

Russia

naminakova@yandex.ru

Associate Prof. Varvara I. Rogacheva, PhD.

Centre of Additional Professional Education

Institute of Law and National Security

Russian Presidential Academy of National Economy and Public Administration (RANEPA)

84/2, 6 Vernadsky Prospect

119606 Moscow

Russia

rogacheva@ranepa.ru 